\title{
Identification of genes differentially expressed during larval molting and metamorphosis of Helicoverpa armigera Du-Juan Dong ${ }^{\dagger}$, Hong-Juan $\mathrm{He}^{\dagger}$, Lian-Qin Chai ${ }^{\dagger}$, Xiao-Juan Jiang, Jin- Xing Wang and Xiao-Fan Zhao*
}

Address: School of Life Sciences, Shandong University, Jinan 250100, China

Email: Du-Juan Dong - dongdujuan@163.com; Hong-Juan He - hehongjuan0727@163.com; Lian-Qin Chai - chailianqin02@163.com; XiaoJuan Jiang - Xiaojuan_Jiang@nni.com.sg; Jin-Xing Wang - jxwang@sdu.edu.cn; Xiao-Fan Zhao* - xfzhao@sdu.edu.cn

* Corresponding author †Equal contributors

Published: 25 June 2007

BMC Developmental Biology 2007, 7:73 doi:10.1186/147/-213X-7-73

This article is available from: http://www.biomedcentral.com/I47I-2/3X/7/73

(C) 2007 Dong et al; licensee BioMed Central Ltd.

This is an Open Access article distributed under the terms of the Creative Commons Attribution License (http://creativecommons.org/licenses/by/2.0), which permits unrestricted use, distribution, and reproduction in any medium, provided the original work is properly cited.
Received: 26 September 2006

Accepted: 25 June 2007

\begin{abstract}
Background: Larval molting and metamorphosis are important physiological processes in the life cycle of the holometabolous insect. We used suppression subtractive hybridization (SSH) to identify genes differentially expressed during larval molting and metamorphosis.

Results: We performed SSH between tissues from a variety of developmental stages, including molting 5th and feeding 6th instar larvae, metamorphically committed and feeding 5 th instar larvae, and feeding 5 th instar and metamorphically committed larvae. One hundred expressed sequence tags (ESTs) were identified and included 73 putative genes with similarity to known genes, and 27 unknown ESTs. SSH results were further characterized by dot blot, Northern blot, and RT-PCR. The expression levels of eleven genes were found to change during larval molting or metamorphosis, suggesting a functional role during these processes.
\end{abstract}

Conclusion: These results provide a new set of genes expressed specifically during larval molt or metamorphosis that are candidates for further studies into the regulatory mechanisms of those stage-specific genes during larval molt and metamorphosis

\section{Background}

Molting is a physiological process common to all ecdysozoan animals, including nematodes and arthropods, during which the old exoskeleton, or cuticle, is shed and replaced by a new exoskeleton. The life cycle of the holometabolous insect is characterized by a series of molts: larval molts, during which the larva progresses from one instar to the next, and metamorphic molts, which lead to pupation and eclosion. Generally, molting consists of two phases, the lethargus, or inactive phase, and ecdysis, or shedding of old cuticle. A cascade of physiological processes occurs during molting, including sepa- ration of the old cuticle from the underlying epidermis (apolysis), secretion of a new cuticle beneath the old, and finally shedding of the old exoskeleton [1]. Subsequent metamorphosis, the transformation of larva to pupa to adult, includes metamorphic molting. During this process, more complicated physiological processes occur, including histolysis of larval tissues, remodeling and formation of adult tissues, in addition to a molting cascade similar to the larval molt. Apoptotic and autophagic programmed cell death pathways are involved in tissue histolysis and remodeling during metamorphosis [2,3]. Insect larval molting and metamorphosis are governed by 
ecdysteroids (20-hydroxyecdysone, 20E) and juvenile hormone $(\mathrm{JH})$, with $20 \mathrm{E}$ orchestrating the molting process and JH determining the nature of the molt [4]. In the presence of $\mathrm{JH}, 20 \mathrm{E}$ directs larval molting. Otherwise, 20E directs metamorphosis. Twenty hydroxyecdysone (20E) and $\mathrm{JH}$ levels increase during the late stages of the final (wandering) instar in Manduca larvae, before pupal ecdysis, and then decrease at the pupal ecdysis. 20E levels peak midway through the pupal stage, but JH does not [4]. Increasing evidence indicates that other hormones and receptors may contribute to the complex developmental pathways associated with metamorphosis [5]. However, the endocrine circuits that regulate molting in response to environmental and physiologic cues are not well understood. Moreover, little is known about the molecular mechanisms regulating release and de novo production of the new exoskeleton [6]. The molecular mechanisms underlying metamorphosis are also enigmatic, although some key regulatory genes have been identified, such as Broad complex, E74B and E93 [2]. In addition, very few genes downstream of Broad complex, E74B and E93 are identified. Therefore, the molecular mechanisms that lead to larval molt and metamorphosis are poorly understood. Nevertheless, much remains to be learned regarding the molecular regulatory processes governing larval molting and metamorphosis.

Tremendous efforts have been made to identify larval molting and metamorphosis genes. Many genes have been shown to be involved in molting or metamorphosis, such as the transcription factors EcR, USP, HR3, Broad C [4], and the programmed cell death pathway genes [7]. The powerful technique of DNA microarray has extended the single-gene approach to the genome level by allowing simultaneous comparison of transcript levels of thousands of genes [8]. Several microarray and functional genomic studies have led to the identification of genes that exhibit a change in expression level at the onset of metamorphosis. For example, microarray technology was used to investigate gene expression changes in response to $20 \mathrm{E}$, and dependent on EcR, at the onset of metamorphosis in Drosophila [9]. Tissue-specific gene expression and ecdysone-regulated genomic networks have also been examined by microarray in Drosophila [10]. Another study found that about one-third of all Drosophila genes undergo changes in expression by examining whole insects at different developmental timepoints [11].

To date, genome-wide studies of molting and metamorphosis have been limited to Drosophila or C. elegans because of the availability of genomic sequence and commercial microarrays for these two models. Thus, no largescale investigation of larval molting and metamorphosis genes has been reported for a non-Dipteran insect. The lepidopteran, Helicoverpa armigera is a notorious crop pest, the world over, and shares molting and metamorphosis features with Manduca sexta and Bombyx mori. Because no genomic sequence or commercial microarrays exist for $H$. armigera, large scale screening of genes expressed differentially expressed during molting and metamorphosis is a great challenge. Initial efforts to study the molecular regulation of these important life cycle changes focused on the $H$. armigera hormone receptor 3 (HHR3) and its expression patterns during larval molting [12]. To discover new larval molting genes in a higher throughput manner, we performed two-dimensional electrophoresis and identified 30 new proteins whose expression increased during larval molting [13]. However, many more genes involved in larval molting and metamorphosis in $H$. armigera remain to be identified.

Suppression subtractive hybridization (SSH) is a powerful method for identifying differentially expressed genes. In this technique, cDNA from one population of cells/tissues is used as the "tester," to reveal cDNAs unique to a second population, the "driver". Nucleotide adaptors are first added to tester CDNAs and these are then hybridized with an excess of driver cDNAs. cDNAs unique to the driver population can then be amplified by PCR, while adaptors from the tester pool suppress amplification of cDNAs common to tester and driver populations [14,15]. Here, we use SSH to identify genes from $H$. armigera that are differentially expressed during larval molting or metamorphosis. These include regulators, hydrolases, and other genes that will further the study of the regulatory mechanisms of insect larval molting and metamorphosis.

\section{Results \\ Identification of genes differentially expressed during larval molting}

cDNAs from five separate tissues from molting 5 th instar larvae (5th-HCS, with head capsule slippage, HCS) were used as the tester and cDNAs from feeding 6th instar larvae (6th-48 h) were used as the driver in five separate rounds of SSH, resulting in 200 cDNAs with molecular masses greater than 300-500 bp. Sequencing revealed 27 putative genes with similarity to annotated genes in Genbank by BLAST search, and 8 novel ESTs (Table 1). Very high frequency genes included the ribosome proteins genes $r p L 27, S 7, S 2$ and $L 23$. Other high frequency genes were CHK1 checkpoint homolog, carboxypeptidase A2 (carbA2) and $h m g 176$. However, most genes appeared at a lower frequency of 1 or 2 times (Fig. 1A).

Next, we grouped our genes according to predicted function, based on similarity to known genes in the National Center of Bioinformatics (NCBI) database, to produce seven main groups: ribosome proteins, rp), hydrolases, immune-related genes, regulators, enzyme, other genes, and unknown ESTs. Among those genes, eight encoded 
Table I: Identification of putative genes from SSH of tester cDNA from molting 5 th instar larvae and driver cDNA from feeding 6 th instar larvae

\begin{tabular}{|c|c|c|c|c|c|}
\hline Classification & No & Tissue Sources & Similar genes in GenBank & E-value & Functions of the genes \\
\hline \multirow[t]{8}{*}{ Ribosome proteins } & 1 & head midgut epidermis & ribosomal protein L27 [S. frugiperda] & le-55 & $\begin{array}{l}\text { participates in both } 50 \mathrm{~S} \text { subunit } \\
\text { assembly and the peptidyl transferase } \\
\text { reaction }\end{array}$ \\
\hline & 2 & head & ribosomal protein S7 [S.frugiperda] & $7 e-23$ & $\begin{array}{l}\text { initiating assembly of the head of the } \\
30 \text { S subunit }\end{array}$ \\
\hline & 3 & fat body midgut & ribosomal protein S2 [B. mori] & $2 \mathrm{e}-40$ & $\begin{array}{l}\text { maintaining balance between the } \\
\text { small and large ribosomal subunits }\end{array}$ \\
\hline & 4 & midgut & $\begin{array}{l}\text { ribosomal protein LI7/23 [Apis } \\
\text { mellifera] }\end{array}$ & $8 e-17$ & $\begin{array}{l}\text { regulator of the p53-MDM2 feedback } \\
\text { regulation }\end{array}$ \\
\hline & 5 & midgut & $\begin{array}{l}\text { ribosomal protein L38 [Plutella } \\
\text { xylostella] }\end{array}$ & $2 \mathrm{e}-17$ & protein of $60 \mathrm{~S}$ ribosomal subunit \\
\hline & 6 & haemocyte & ribosomal protein S24 [B. mori] & $|e-2|$ & protein of $40 \mathrm{~S}$ ribosomal subunit \\
\hline & 7 & head & ribosomal protein L22 [S. frugiperda] & $2 e-29$ & large ribosomal subunit \\
\hline & 8 & midgut & ribosomal protein LI3 [S. frugiperda] & $3 e-43$ & $60 \mathrm{~S}$ ribosomal subunit protein \\
\hline \multirow[t]{7}{*}{ Hydrolases } & 9 & fat body & $\begin{array}{l}\text { molting fluid carboxypeptidase } A[B \text {. } \\
\text { mori]-I }\end{array}$ & $3 e-31$ & $\begin{array}{l}\text { pupal ecdysis, recycling of the amino } \\
\text { acids }\end{array}$ \\
\hline & 10 & haemocyte & $\begin{array}{l}\text { cathepsin L like protease [Glossina } \\
\text { morsitans morsitans] }\end{array}$ & le-25 & $\begin{array}{l}\text { larval molting and cuticle and eggshell } \\
\text { remodeling }\end{array}$ \\
\hline & 11 & midgut & $\begin{array}{l}\text { trypsinogen } Y \text { precursor [Gadus } \\
\text { morhua] }\end{array}$ & $2 e-06$ & hydrolase \\
\hline & 12 & epidermis & $\begin{array}{l}\text { molting fluid carboxypeptidase } A[B \text {. } \\
\text { mori]-2 }\end{array}$ & le-54 & molting-related \\
\hline & 13 & epidermis & $\begin{array}{l}\text { plasminogen activator, tissue [Mus } \\
\text { musculus] }\end{array}$ & $7 e-07$ & hydrolase \\
\hline & 14 & midgut & lipase-I [B. mandarina $]$ & $2 e-23$ & lipid digestion \\
\hline & 15 & fatbody & $\begin{array}{l}\text { chitinase }[H \text {. armigera] (BLAST by } \\
\text { nucleotide acids) }\end{array}$ & 0.42 & hydrolase \\
\hline \multirow[t]{2}{*}{ Immune-related Genes } & 16 & haemocyte & $\begin{array}{l}\text { lipopolysaccharide binding protein } \\
\text { [B. mori] }\end{array}$ & $6 e-26$ & immune \\
\hline & 17 & fat body & $\begin{array}{l}\text { immune reactive putative protease } \\
\text { inhibitor PrInh6 [Glossinamorsitans } \\
\text { morsitans] }\end{array}$ & $2 e-09$ & immune \\
\hline \multirow[t]{3}{*}{ Regulators } & 18 & fat body haemocyte & $\begin{array}{l}\text { CHKI checkpoint homolog } \\
\text { [Xenopus tropicalis }]\end{array}$ & $2 e-07$ & $\begin{array}{l}\text { DNA damage and replication } \\
\text { checkpoints }\end{array}$ \\
\hline & 19 & midgut & $\begin{array}{l}\text { CGI3323-PA [D. melanogaster] } \\
\text { (similar to hmg I76) }\end{array}$ & $6 e-05$ & - \\
\hline & 20 & epidermis & $\begin{array}{l}\text { thymosin beta homologue [Ciona } \\
\text { intestinalis] }\end{array}$ & 0.55 & $\begin{array}{l}\text { actin-remodeling, wound healing, } \\
\text { angiogenesis }\end{array}$ \\
\hline enzyme & 21 & head & Na-K-ATPase [Anopheles gambiae] & $2 e-09$ & enzyme \\
\hline \multirow[t]{6}{*}{ Others } & 22 & midgut & $\begin{array}{l}\text { TNF receptor homolog } 3 \text { [Rattus } \\
\text { norvegicus] }\end{array}$ & 3 & $\begin{array}{l}\text { cellular proliferation, differentiation } \\
\text { and programmed cell death }\end{array}$ \\
\hline & 23 & epidermis & Titin-like protein [B. mori] & $8 e-15$ & roles in chromosomes and muscles \\
\hline & 24 & midgut & Acyla-CoA binding protein [B. mori] & $4 e-06$ & intracellular acyl-CoA transporters \\
\hline & 25 & fat body & $\begin{array}{l}\text { hypothetical protein Llacc01000286 } \\
\text { [Lactococcus lactis subsp.cremoris } \\
\text { SKII] }\end{array}$ & le-24 & - \\
\hline & 26 & head & $\begin{array}{l}\text { CG32972-PB, isoform B } \\
\text { [D.melanogaster] }\end{array}$ & 0.011 & - \\
\hline & 27 & fat body & $\begin{array}{l}\text { I6S rRNA [S. frugiperda] (BLAST by } \\
\text { nucleotide acids) }\end{array}$ & $7 e-17$ & - \\
\hline Unknown ESTs & $28-35$ & epidermis & Unknown proteins & & - \\
\hline
\end{tabular}




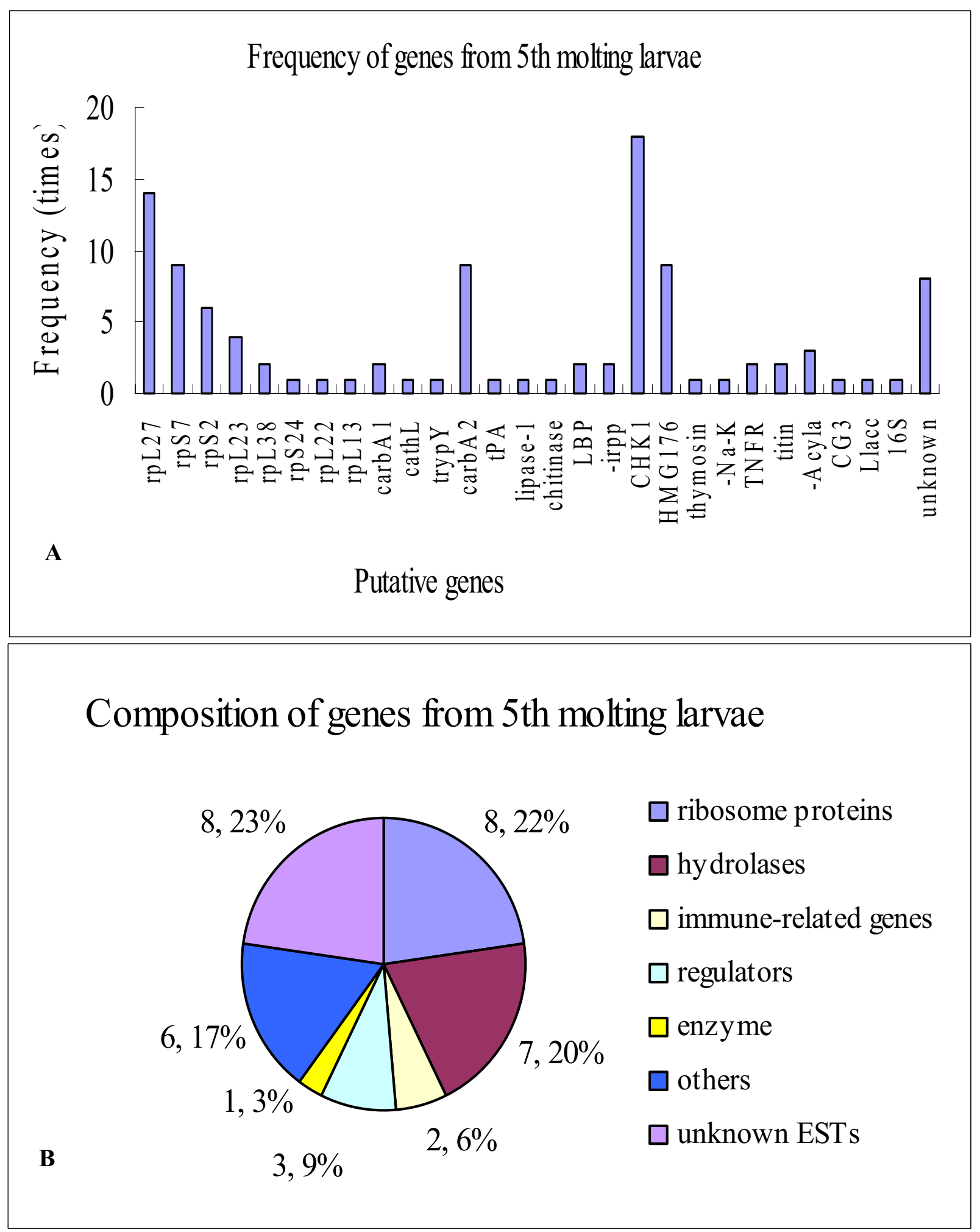

Figure I

Genes identified in 5th instar molting larvae. A) Gene frequency. B) Gene transcription composition (number, percentage). 
ribosome proteins (22\% of the genes), and seven encoded hydrolases, including carbA1 and c arbA2,cathepsin $L$ (cathL), trypsinogen $Y$, tissue plasminogen activator (tPA), lipase, and a chitinase-like gene (20\% of the genes). The other encoded lipopolysaccharide binding protein (lbp), immune reactive putative protease inhibitor (irpp-inhibitor), CHK1 checkpoint homolog, and other putative genes, respectively (Fig. 1B).

\section{Identification of genes differentially expressed during metamorphic molting}

Two hundreds cDNA fragments were sequenced from SSHs between tester cDNAs of metamorphically committed larvae (6th-72, 96 and $120 \mathrm{~h}$ ) and driver cDNAs of feeding 5th instar larvae (5th-24 h). By BLAST search, 31 putative genes with similarity to annotated Genbank genes, and 16 unknown ESTs were identified (Table 2). The most frequently appearing genes were ribosome protein encoding genes, including $r p L 27, S 23$ and $S 7$. Another frequently occurring gene was the basic juvenile hormone-suppressible protein (BJHSP), which was not detected in 5 th molting or 5th feeding larvae by SSH. Other genes identified were specifically detected only once or twice in this SSH (Fig. 2A).

These genes were classified into eight groups, as described above: ribosome proteins, hydrolases, immune-related genes, regulators, enzymes, transporters, others and unknown ESTs. A large number of unknown ESTs were common to tissues from the metamorphic molt (Fig. 2B). In addition, some important genes such as BJHSP, DEADbox RNA helicases, basic leucine zipper (bzip), and guanine nucleotide binding protein gamma subunit (G-protein- $\gamma$ ) were detected at these stage.

\section{Identification of genes differentially expressed in feeding 5th instar larvae}

SSHs between feeding 5th instar larvae tester and metamorphically committed larvae (6th-72, 96 and $120 \mathrm{~h}$ ) driver were performed to identify cDNAs enriched in feeding 5th instar larvae. In total, $230 \mathrm{cDNA}$ fragments were sequenced following PCR. Of these, 23 putative genes and 3 unknown ESTs were identified (Table 3). Ribosome protein encoding genes were the most common, especially rpL27 that appeared very higher frequency, whereas other ribosome proteins had lower frequencies. Another high frequency gene was the gene encoding retinoblastomabinding protein 6 isoform 2-like, which was not identified in molting 5th instar or metamorphically committed larvae by SSH. Other lower frequency genes were specifically detected in feeding 5 th instar larvae (Fig. 3A).

Genes were classified into 6 groups, according to similarity, including ribosome proteins, hydrolases, regulators, enzymes, other genes, and unknown ESTs (Fig. 3B). Inter- estingly, three high frequency hydrolases genes were all vitellogenic-like carboxypeptidase, although their sequences were quite divergent. These three genes were detected in epidermis of feeding 5 th instar larvae. The genes encoding ecdysteroid-regulated protein and a cytochrome P450 likeTBP-like gene were also detected from feeding 5 th instar larvae. In addition, many genes with unknown function were detected.

\section{Analysis of SSH efficacy by dot blot hybridization}

To analyze the efficacy of SSHs, dot blot hybridization was performed using $70 \mathrm{cDNA}$ fragments that were randomly chosen from the set of differentially expressed genes resulting from $\mathrm{SSH}$ between molting 5 th instar epidermis tester and feeding 6 th instar epidermis driver. Blots were hybridized with probes made from cDNA of molting 5th instar larval epidermis. Nearly all of the 70 dots stained positively. In contrast, when blots were hybridized with probes made from cDNA of feeding 6th larval epidermis, only 3 dots were obviously positively stained. This result indicates that $95 \%$ of the cDNAs detected by SSH were differentially expressed during larval molting, while 5\% of the cDNAs may not be molting-specific (Fig. 4).

\section{Northern blot analysis of gene expression}

Two genes identified by SSH were chosen for analysis by Northern blot in different tissues at various developmental stages. One of these was hmg176, which was identified in molting 5th instar midguts by SSH between molting 5 th instar larvae tester and feeding 6th instar driver. The other gene examined was cathL, identified in molting 5 th instar hemocytes by the same SSH. The results indicated that hmg176 was highly expressed in the midgut during larval molting, but was not detected in 6th-48 h larvae. Similarly, cathL was obviously upregulated in hemocytes of molting larvae (Fig. 5). These data suggest that some of the ESTs identified by SSHs do represent stage-specific genes.

\section{Semi-quantitative RT-PCR analysis of larval molting or metamorphosis genes}

To further analyze larval molting and metamorphosis genes and to examine gene expression patterns in different tissues, such as head, midgut, fat body, epidermis, and hemocytes during development, 22 putatively differentially expressed genes were randomly chosen for semiquantitative RT-PCR analysis. These included 18 genes from SSHs between molting 5th instar larva testers and feeding 6th instar larva drivers, 3 genes from SSHs between metamorphically committed larva testers and feeding 5th instar drivers, and 1 gene from SSHs between feeding 5 th instar testers and metamorphically committed larva drivers. The beta-actin gene was used as a positive control. 
Table 2: Identification of putative genes from SSH of tester cDNA from metamorphically committed larvae and driver cDNA from feeding 5th instar larvae

\begin{tabular}{|c|c|c|c|c|c|}
\hline Classification & No & Tissue sources & Similar genes in GenBank & E-value & Functions of the genes \\
\hline \multirow[t]{7}{*}{ Ribosome proteins } & I & epidermis & $\begin{array}{l}\text { ribosome protein } \$ 23 \\
{[\text { D.melanogaster }]}\end{array}$ & $4 e-06$ & see Table I \\
\hline & 2 & $\begin{array}{l}\text { epidermis Fat body } \\
\text { midgut head }\end{array}$ & ribosome protein L27 [S. frugiperda] & $4 e-54$ & see Table I \\
\hline & 3 & fat body head & ribosome protein S7 [B.mori] & $7 e-24$ & see Table I \\
\hline & 4 & $\begin{array}{l}\text { epidermis midgut } \\
\text { head }\end{array}$ & $\begin{array}{l}\text { ribosome protein LI3 [Helicoverpa } \\
\text { zea] }\end{array}$ & $2 e-24$ & see Table I \\
\hline & 5 & head & ribosome protein L9 [B. mori] & $2 e-26$ & compose the large ribosomal subunit \\
\hline & 6 & head & ribosome protein LII [B. mori] & $5 e-22$ & large ribosomal subunit protein \\
\hline & 7 & head & $\begin{array}{l}\text { ribosomal protein L4I [S. frugiperda] } \\
\text { (BLAST by nucleotide acids) }\end{array}$ & le-23 & mitochondrial ribosomal protein \\
\hline \multirow[t]{2}{*}{ Hydrolases } & 8 & fat body & $\begin{array}{l}\text { DEAD box RNA helicase [C. } \\
\text { fumiferana] }\end{array}$ & le-25 & disrupt RNA-protein interactions \\
\hline & 9 & midgut & ribonuclease [Ceratitis capitata] & $8 e-31$ & degradation of RNA \\
\hline \multirow[t]{2}{*}{ Immune-related proteins } & 10 & midgut & immune inducible protein $[$ B. mori] & $3 e-11$ & immune-response \\
\hline & 11 & midgut & lysozyme [Heliothis virescens] & $1 \mathrm{e}-17$ & immune \\
\hline \multirow[t]{5}{*}{ Regulator } & 12 & epidermis & $\begin{array}{l}\text { basic juvenile hormone-suppressible } \\
\text { protein } 2 \text { precursor (BJHSP2) [S. } \\
\text { litura] }\end{array}$ & $6 e-08$ & metamorphosis related \\
\hline & 13 & epidermis & promoting protein [B. mori] & $3 e-12$ & $\begin{array}{l}\text { promoting in vitro replication of } \\
\text { nucleopolyhedrovirus }\end{array}$ \\
\hline & 14 & head & $\begin{array}{l}\text { basic leucine zipper and W2 } \\
\text { domains } 2[R . \text { norvegicus }]\end{array}$ & 0.009 & $\begin{array}{l}\text { transcription factor controlling } \\
\text { molting and metamorphosis }\end{array}$ \\
\hline & 15 & fat body & $\begin{array}{l}\text { guanine nucleotide binding protein } \\
\text { gamma subunit-like protein }[P . \\
\text { xylostella] }\end{array}$ & $4 e-22$ & Signal transduction \\
\hline & 16 & midgut & $\begin{array}{l}\text { conserved hypothetical protein } \\
\text { [Lactococcus lactis] }\end{array}$ & $5 e-19$ & - \\
\hline \multirow[t]{3}{*}{ Enzyme } & 17 & fat body & $\begin{array}{l}\text { ATP synthase subunit } 6 \\
\text { [Phthonandria atrilineata] }\end{array}$ & 0.15 & ATP synthase \\
\hline & 18 & midgut & luciferase [Luciola lateralis] & $8 e-13$ & Fatty acyl-CoA synthetase \\
\hline & 19 & head & $\begin{array}{l}\text { IMP dehydrogenase/GMP reductase } \\
{[\text { Desulfuromonas acetoxidans DSM }} \\
684]\end{array}$ & 0.31 & $\begin{array}{l}\text { re-utilization of free intracellular } \\
\text { bases and purine nucleosides }\end{array}$ \\
\hline \multirow[t]{2}{*}{ Transporter } & 20 & epidermis & $\begin{array}{l}\text { cation channel family protein } \\
\text { [Tetrahymena thermophila SB2 I0] }\end{array}$ & 6.1 & $\mathrm{Ca}^{2+}$-permeable ion channel \\
\hline & 21 & midgut & $\begin{array}{l}\text { nuclear transport factor } 2 \text { [Aedes } \\
\text { aegypti] }\end{array}$ & $3 e-24$ & targeting proteins into the nucleus \\
\hline \multirow[t]{10}{*}{ Others } & 22 & midgut & $\begin{array}{l}\text { phenoloxidase inhibitor protein } \\
\text { [Anopheles gambiae] }\end{array}$ & 0.006 & enzyme inhibitor \\
\hline & 23 & epidermis & $\begin{array}{l}\text { apolipophorin-III precursor [Agrius } \\
\text { convolvuli] }\end{array}$ & le- 12 & lipid transfer and cell death \\
\hline & 24 & midgut & $\begin{array}{l}\text { CGI2I20-PA [Tribolium } \\
\text { castaneum] }\end{array}$ & $2 e-09$ & - \\
\hline & 25 & epidermis & hexamerine $[H$. armigera $]$ & $2 e-04$ & $\begin{array}{l}\text { storage protein during } \\
\text { metamorphosis }\end{array}$ \\
\hline & 26 & midgut & cobatoxin long form B [S. frugiperda] & $8 e-05$ & - \\
\hline & 27 & midgut & $\begin{array}{l}\text { sensory neuron membrane protein } \\
2[M . \text { sexta] }\end{array}$ & $4 e-05$ & - \\
\hline & 28 & head & $\begin{array}{l}60 \mathrm{~S} \text { ribosome subunit biogenesis } \\
\text { protein [Theileria annulata] }\end{array}$ & 9.7 & - \\
\hline & 29 & midgut & $\begin{array}{l}\text { ENSANGP000000I7373 [Apis } \\
\text { mellifera] }\end{array}$ & $3 e-10$ & - \\
\hline & 30 & head & CGI2926-PA [T. castaneum] & $3 e-19$ & - \\
\hline & 31 & midgut & $\begin{array}{l}\text { deoxyribodipyrimidine photolyase } \\
\text { [Marinobacter aquaeolei VT8] }\end{array}$ & 6.1 & - \\
\hline Unknown ESTs & $32-47$ & $\begin{array}{l}\text { midgut epidermis fat } \\
\text { body head }\end{array}$ & & & \\
\hline
\end{tabular}




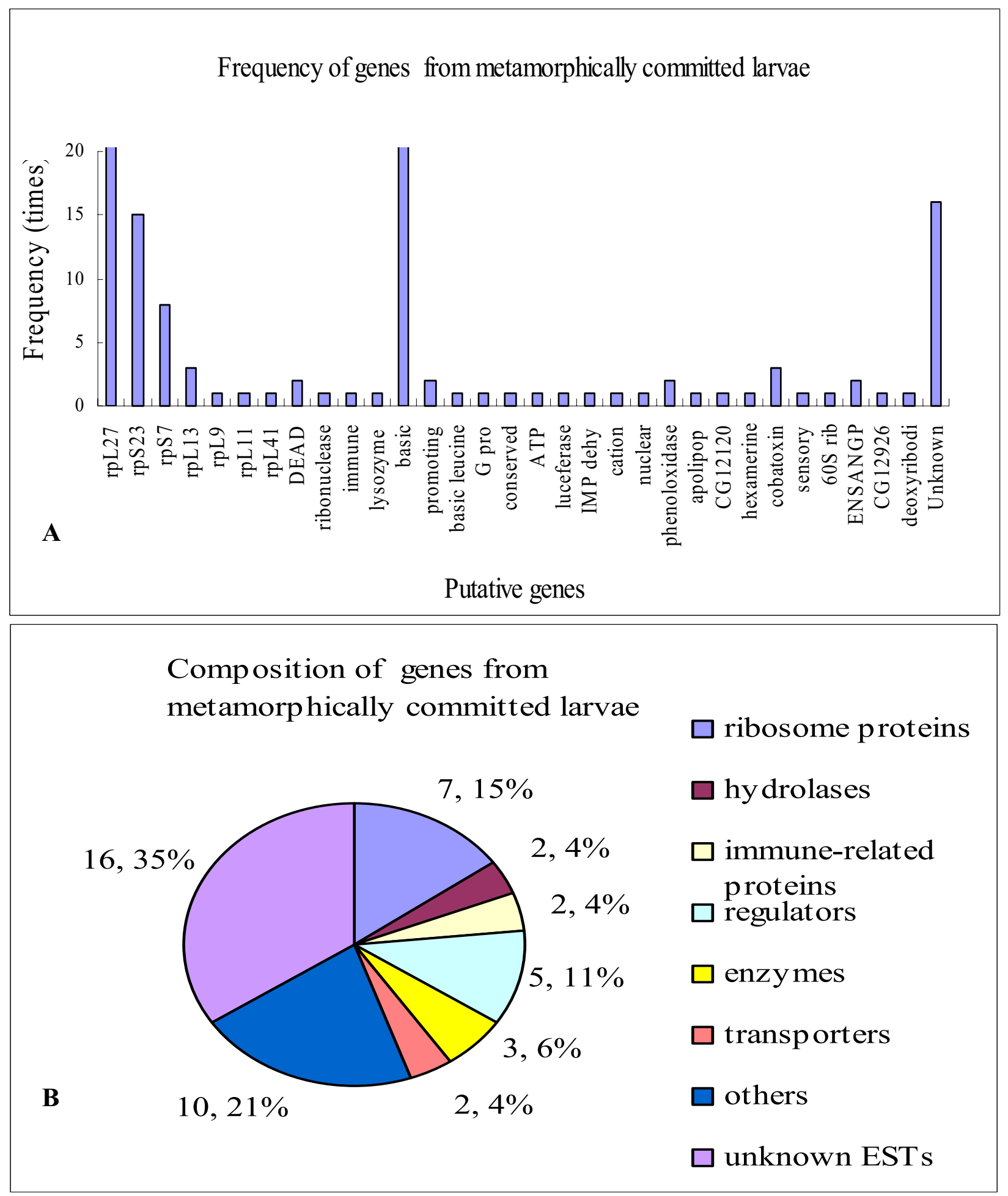

Figure 2

Genes identified in metamorphically committed larvae. A) Gene frequency. B) Gene transcription composition (number, percentage). 
Table 3: Identification of putative genes from SSH of tester cDNA from feeding 5th instar larvae and driver cDNA of metamorphically committed larvae

\begin{tabular}{|c|c|c|c|c|c|}
\hline Classification & No & $\begin{array}{l}\text { Tissue } \\
\text { sources }\end{array}$ & Similar genes in GenBank & E-value & Functions of the genes \\
\hline \multirow[t]{7}{*}{ ribosome proteins } & I & $\begin{array}{l}\text { head midgut } \\
\text { epidermis }\end{array}$ & ribosomal protein L27 [S. frugiperda] & $9 e-55$ & see Table I \\
\hline & 2 & midget & ribosomal protein L22 [S. frugiperda] & $9 e-07$ & see Table I \\
\hline & 3 & midgut & ribosomal protein S29 [S. frugiperda] & $5 e-29$ & apoptotic inducer \\
\hline & 4 & head & ribosomal protein LI $3[$ H. zea] & $5 e-43$ & see Table I \\
\hline & 5 & midgut & ribosomal protein L28 [S. frugiperda] & $6 e-38$ & ribosome assembly \\
\hline & 6 & midgut & ribosomal protein S7 [Plutella xylostella] & $7 e-25$ & see Table I \\
\hline & 7 & midgut & ribosomal protein SIO [Lonomia obliqua] & le-33 & mitochondrial import proteins \\
\hline \multirow[t]{3}{*}{ hydrolases } & 8 & epidermis & $\begin{array}{l}\text { carboxypeptidase, vitellogenic-like-I [T. } \\
\text { castaneum] }\end{array}$ & le-29 & inflammatory protease cascade \\
\hline & 9 & epidermis & $\begin{array}{l}\text { carboxypeptidase, vitellogenic-like-2 [T. } \\
\text { castaneum] }\end{array}$ & $2 e-16$ & inflammatory protease cascade \\
\hline & 10 & epidermis & $\begin{array}{l}\text { carboxypeptidase, vitellogenic-like-3 [D. } \\
\text { rerio] }\end{array}$ & $6 e-04$ & inflammatory protease cascade \\
\hline \multirow[t]{3}{*}{ regulators } & 11 & epidermis & apoptosis inhibitor [Bos taurus] & $1 e-16$ & candidate of molting-related protein \\
\hline & 12 & midgut & $\begin{array}{l}\text { ecdysteroid-regulated protein [Litopenaeus } \\
\text { vannamei] }\end{array}$ & $5 e-19$ & molting-related protein \\
\hline & 13 & head & $\begin{array}{l}\text { retinoblastoma-binding protein } 6 \text { isoform } 2 \\
\text { [D. rerio] }\end{array}$ & 0.87 & candidate of molting-related protein \\
\hline \multirow[t]{2}{*}{ enzyme } & 14 & head fat body & glutathione S-transferase [C. fumiferana] & $9 e-09$ & detoxification of electrophilic compounds \\
\hline & 15 & midgut & $\begin{array}{l}\text { cytochrome P450 like_TBP [Nicotiana } \\
\text { tabacum] }\end{array}$ & $1 \mathrm{e}-10$ & - \\
\hline \multirow[t]{8}{*}{ others } & 16 & epidermis & ENSANGP000000। 4082 [A. gambiae] & $1 \mathrm{e}-17$ & - \\
\hline & 17 & epidermis & CG803I-PA [D. Melanogaster] & le-35 & - \\
\hline & 18 & midgut & CGI3607-PA [T. castaneum] & $1 \mathrm{e}-18$ & - \\
\hline & 19 & midgut & CGI3922-PA [T.castaneum] & $4 e-05$ & - \\
\hline & 20 & midgut & $\begin{array}{l}\text { fasciclin } 3 \text { CG5803-PA-isoform A [D. } \\
\text { melanogaster] }\end{array}$ & 8.0 & - \\
\hline & 21 & midgut & CGI0733-PAisoform [T. castaneum] & $8 e-06$ & - \\
\hline & 22 & fat body & keratin associated protein 7 [Pan troglodytes] & 0.98 & - \\
\hline & 23 & epidermis & $\begin{array}{l}\text { sensory box histidine kinase/response } \\
\text { regulator }\end{array}$ & 6.2 & - \\
\hline Unknown ESTs & $24-26$ & $\begin{array}{l}\text { midgut fat } \\
\text { body } \\
\text { epidermis }\end{array}$ & unknown proteins & & - \\
\hline
\end{tabular}

Of these genes, 8 genes were differentially detectable during larval molting. Some genes were known larval molting genes, such as carbA1, irpp-inhibitor, hmg176, carbA2 and a tumor necrosis factor receptor (TNFR)-like gene. Interestingly, these genes exhibited distinct tissue-specific expression patterns as well. For instance, carbA1 was mainly detected in molting larval fat bodies, epidermis and hemocytes, the irpp-inhibitor was mainly detected in molting larval fat bodies and epidermis, $h m g 176$ was mainly expressed in molting larval midguts, carbA2 was mainly detected in molting larval epidermis; and the TNFR-like gene was mainly detected in molting larval heads, midguts and fat bodies. An unknown EST was detectable at higher levels in all 5 tissues of molting larvae than in feeding larvae. CathL was detected at higher levels in molting larval hemocytes than feeding larval hemocytes, consistent with Northern blot analysis. The tPA gene was detected at higher levels in molting larval fat bodies compared to feeding larval fat bodies.
Some genes exhibited differential expression in different tissues during larval molting. For example, the $\mathrm{Na}-\mathrm{K}$ ATPase-like gene was detected at higher levels in the epidermis, but not in the head, midgut, or hemocytes of molting larvae. Titin appeared to be expressed at higher levels in the midgut, but not in other tissues, of molting larvae. Trypsinogen Y precursor and lipase only exhibited increased expression in molting larval fat bodies compared with other detected tissues.

Some genes did not show an obvious relationship to larval molting. For example, lbp was not differentially detected between larval molting and feeding by semiquantitative RT-PCR, although it was detected specifically in hemocytes. Expression of the thymosin beta homologuelike gene, rpL27 and $S 7$ were detected at almost constant levels in molting and feeding larval tissues. RpL23 and the hypothetical protein gene (llacc) appeared higher expression during feeding in some tissues (Fig. 6A). 


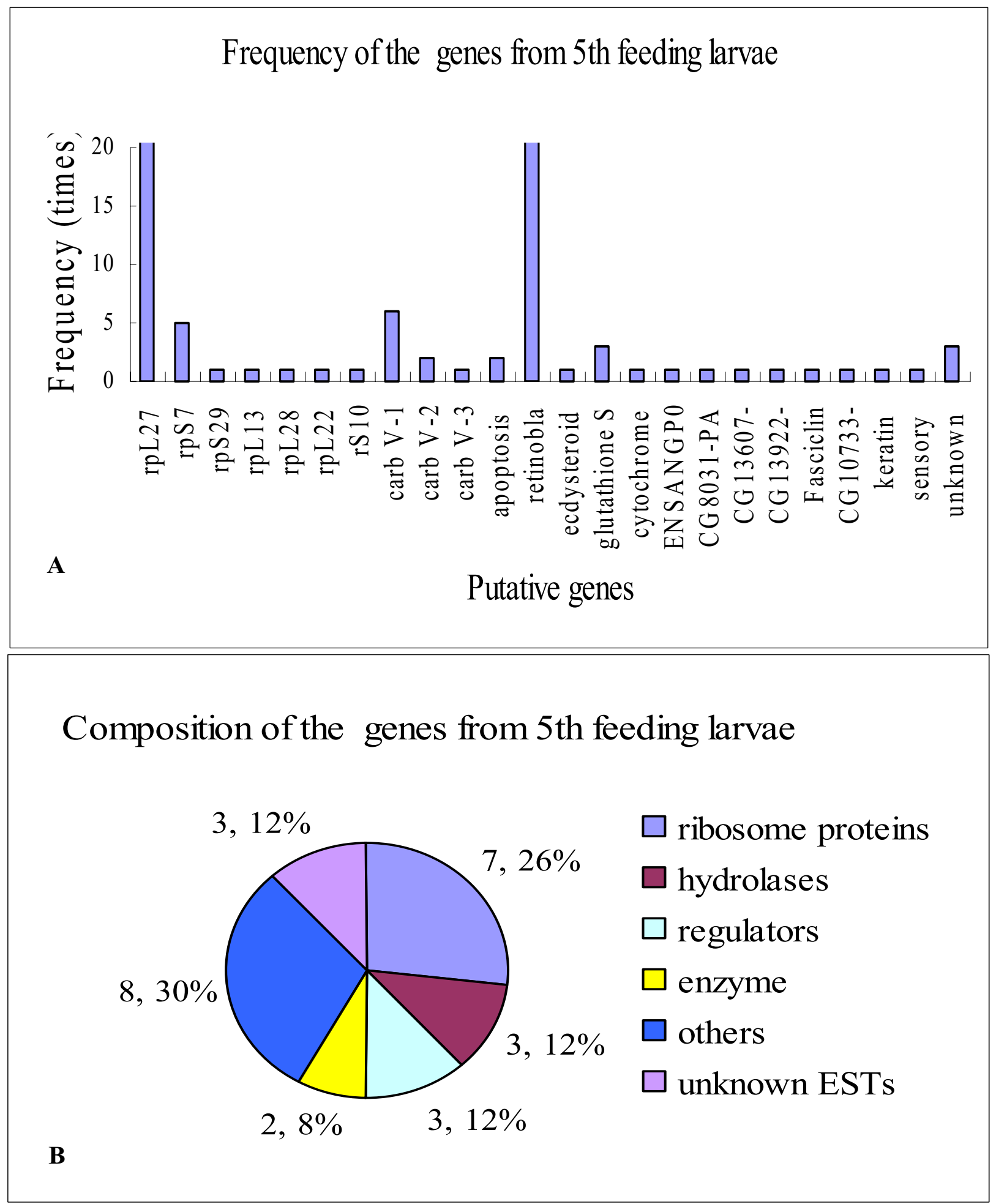

Figure 3

Genes identified in 5th instar feeding larvae. A) Gene frequency. B) Gene composition (number, percentage). 


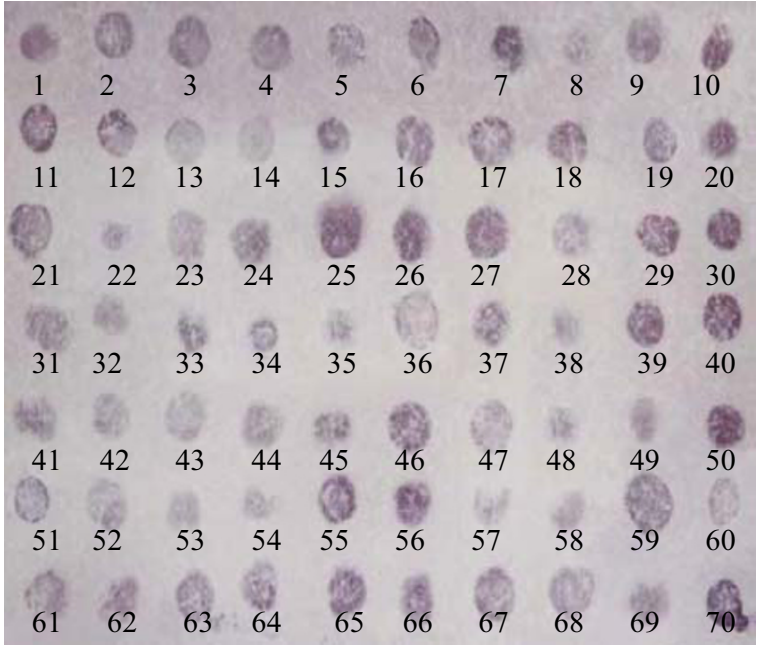

A

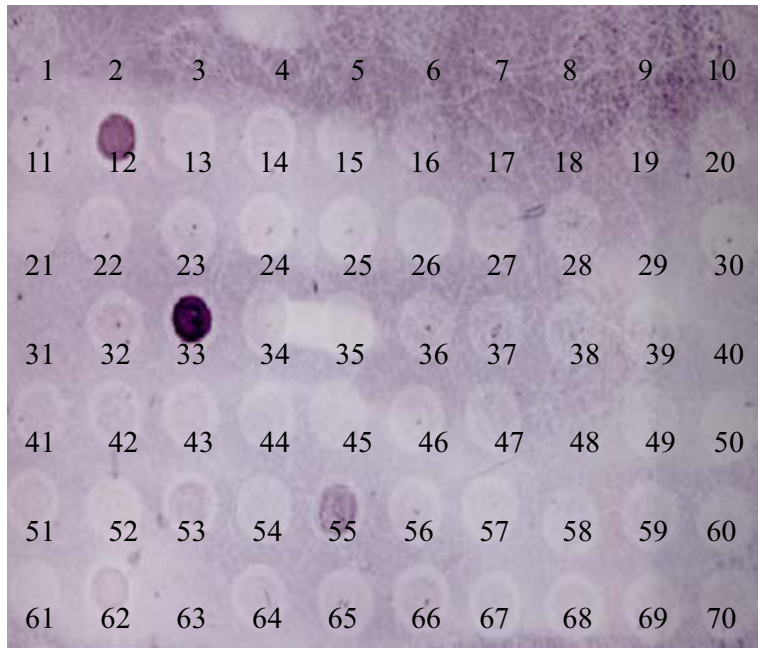

B

\section{Figure 4}

Dot blot hybridization of SSH from molting 5th instar epidermis tester and feeding 6th instar epidermis driver. A) Blots with spotted with cDNA fragments from SSH were hybridized with probes made from molting 5 th instar epidermal mRNA. B) Blots hybridized with probes made from feeding 6th instar epidermis.

Three genes were differentially detected by semi-quantitative RT-PCR in a tissue-specific manner during metamorphosis. These were the genes encoding the gamma subunit of guanine nucleotide binding protein (G-protein- $\gamma$ ), nuclear transport factor-2 (NTF-2) and rpL11. The G-protein- $\gamma$ was detected at higher levels in the epidermis, midgut and fat

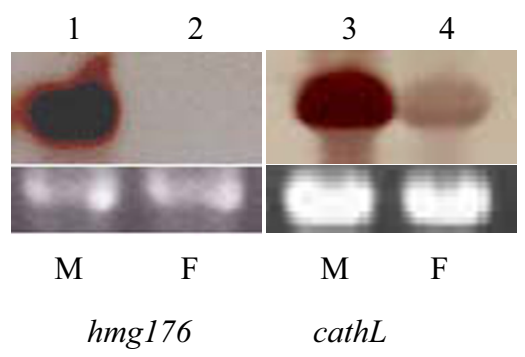

\section{Figure 5}

Northern Blot analysis of the expression of $\mathrm{hmg} / 76$ and cathL in molting 5 th and feeding 6th instar larvae. Lanes I to 4: midgut from molting 5 th instar larvae, midgut from feeding 6th instar larvae, hemocytes from molting 5th instar larvae, and hemocytes from feeding 6th instar larvae. $M=5$ th-HCS, $F=$ feeding. body of the metamorphically committed larvae in 6th-72 or 6th-96 h compared with the tissues from feeding 5 th larvae. The NTF-2 was also detected at higher levels in the midgut of metamorphically committed larvae. The rpL11 was detected at higher levels during metamorphosis and in all 4 examined tissues compared with the tissues from feeding 5th larvae. In contrast, the ecdysteroid-regulated gene was upregulated in the tissues from feeding larvae, which is consistent with the fact that it was detected in feeding 5th instar larvae by SSH (Fig. 6B).

\section{Discussion}

We identified 100 ESTs, including 73 putative genes that were similar to genes in Genbank, and 27 unknown ESTs by SSH of larval tissues. Most similar genes had E-values below 0.01, while less similar genes had E-values greater than 0.01 (Tables 123). Eleven of the putative genes were differentially detectable during larval molting or metamorphosis via semi-quantitative RT-PCR, including regulatory genes expressed during molt and metamorphosis such as NTF-2, G-proteins, and the downstream genes that may play a direct role in the molting and metamorphosis such as carbA2 and cathL. Expression levels of these genes clearly correlated with larval molting or metamorphosis in a largely tissue-specific or developmental stage-specific manner by semi-quantitative RT-PCR analysis. Importantly some of these genes have been reported to play a 


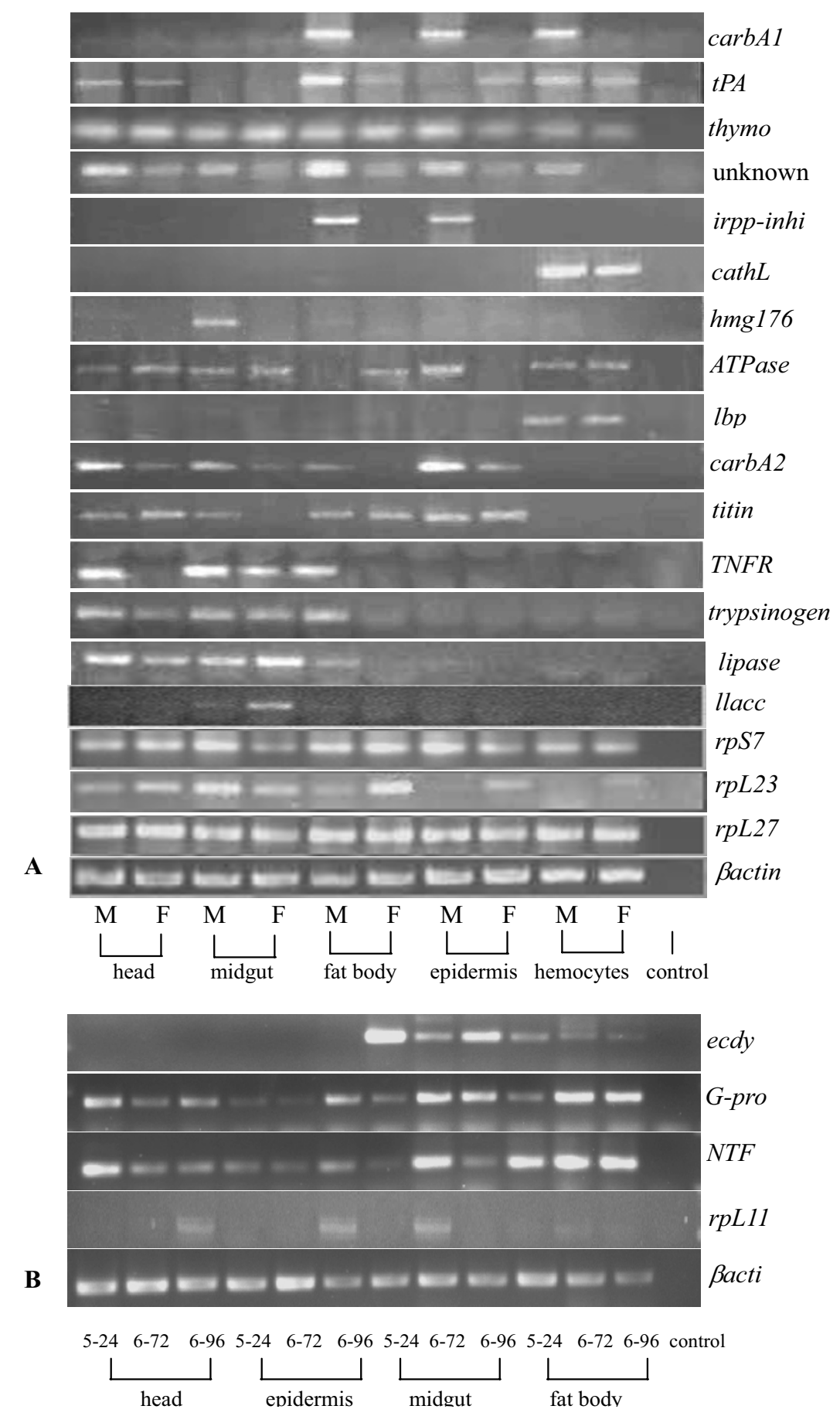

\section{Figure 6}

Semi-quantitative RT-PCR analysis of gene expression in tissues from different developmental stages. Panel A) Gene expression during larval molting and feeding, $\mathrm{M}=$ molting 5 th instar larvae (5th-HCS), $\mathrm{F}=$ feeding 6th instar larvae (6th-48 h). Panel B) gene expression during metamorphosis. 5th-24 = 5th instar larvae $24 \mathrm{~h}$ after ecdysis, 6th-72 h=72 h after ecdysis (wandering$0 \mathrm{~d}$, metamorphically committed larvae); 6th-96 h, $96 \mathrm{~h}$ after ecdysis (wandering-I d, metamorphically committed larvae). 
role in larval molting or metamorphosis. For examples, carbA2 has been reported to be a molting gene in Bombyx, and is expressed during molting in the epithelial tissues [16]. The CarbA2 protein has been suggested to degrade old cuticle during molting and to contribute to recycling of the amino acids in this tissue [16]. CathL, which encodes a cysteine proteinase, is involved in larval molting and cuticle and eggshell remodeling in Brugia pahangi [17]. Other genes identified in this study have not been previously known to play a role in molting or metamorphosis. Their predicted function, based on similarity, however, supports the notion that these genes participate in regulation of larval molting or metamorphosis. For instance, nuclear transport factor-2 (NTF-2) targets proteins to the nucleus in yeast and mammalian cells in culture [18]. The gamma subunit of guanine nucleotide binding protein (G-protein- $\gamma$ ) is an essential component of one of the most prevalent signaling systems in mammalian cells. The fact that NTF-2 and G-protein- $\gamma$ are upregulated during metamorphosis suggests that they participate in metamorphosis.

Some genes identified in this study, based on functions of similar genes, probably participate in larval molting or metamorphosis, although they have not yet been demonstrated to be upregulated in larval molting or metamorphosis in this study. For instance, the basic-leucine zipper gene, controls molting and metamorphosis and is likely to be involved in bZIP signaling pathways in Drosophila [19]. The basic juvenile hormone-suppressible protein 2 (BJHSP2), a juvenile hormone-sensitive protein, expresses and accumulates in the last instar larvae of Trichoplusia $n i$ [20]. The DEAD box RNA helicase and leucine-rich repeat genes are important in molting C. elegans [6]. The Chk1 checkpoint protein was reported to monitor the state of DNA and can delay or arrest the cell cycle at multiple points [21]. The ribonuclease selectively attacks malignant cells, triggering an apoptotic response and inhibiting protein synthesis [22]. These putative genes represent attractive targets for further study into their functions in larval molting and metamorphosis.

Ribosomal proteins have been reported to participate in various cellular processes besides protein biosynthesis. They not only act as components of the translation apparatus, but also regulate cell proliferation and apoptosis [23]. For example, rpL11 associates with and inhibits the transcriptional activity of peroxisome proliferator-activated receptor-alpha [24]. RpL23 regulates p53-MDM2 feedback and the HDM2-p53 pathway $[25,26]$. Mitochondrial ribosomal protein 441 plays an important role in p53-induced mitochondrion-dependent apoptosis by enhancing p53 stability and contributing to p53-induced apoptosis $[27,28]$. RpS29 induces apoptosis in H520 cells $[29,30]$. RpS10 participates in both transcription and translation [31]. We detected these ribosome proteins, and they appear to be highly conserved. Among these, $r p L 11$ was differentially expressed during metamorphosis. Whether or not other ribosome proteins participate in larval molting and metamorphosis need further study.

Interestingly, several putative immune-related genes were identified in molting larvae in this study. For instance, a lysozyme was identified in metamorphically committed larvae. Interestingly, a lysozyme has also been reported to be upregulated during larval metamorphosis in $M$. sexta, and has been proposed to provide protection from bacterial infection [32]. Other immune-related genes including the immune inducible protein and IRPP-inhibitor might play a similar role. These observations provide evidence that some immune-related genes are deferentially expressed during larval molting or metamorphosis.

We also detected an ecdysteroid-regulated protein-like gene encoding an ML domain (MD-2-related lipid-recognition domain) in feeding 5th instar larvae. Single ML domain proteins are predicted to form a beta-rich fold containing multiple strands and to mediate diverse biological functions through interaction with specific lipids [33]. The function of this gene in larval development is unknown. In addition, three kinds of carboxypeptidase vitellogenic-like genes ( $c p v l)$ were detected in the epidermis of feeding 5 th instar larvae. Human $c p v l$ is upregulated during the maturation of monocytes (MO) to macrophages, and is involved in antigen processing, the secretory pathway and/or in actin remodeling and lamellipodium formation [34,35]. Because these genes were detected in feeding 5th instar feeding larvae, they may play important roles in larval growth and development.

We examined the efficacy of SSH by dot blot, Northern blot and RT-PCR. Dot blot analysis of CDNAs from the epidermis of molting 5th instar tester and feeding 6th instar driver suggested the efficacy was $95 \%$. Northern blot analysis indicated that some were differentially expressed during larval molting. However, RT-PCR analysis suggested that only 11 of the 22 examined genes were differentially expressed during larval molting or metamorphosis, and 4 genes, including the Na-K-ATPase-like, titin, trypsinogen $Y$ precursor, and lipase, were only upregulated in some tissues during larval molting. Therefore, the efficacy of SSH was not as high as indicated by the dot blot analysis. This discrepancy might be due to limitation in sensitivity of the dot blot.

Intriguingly, several known genes critical for larval molting and metamorphosis in other species were not identified in this study. One possible explanation might be because that transcripts of these genes, most of them are transcription factors, are extremely rare, or they are 
expressed for a very short time. Another possible explanation is that too few cDNAs were sequenced.

Finally, certain genes, including $r p L 27, S 7$, and $L 13$ were detected at higher levels in all SSHs. This might be due to incomplete subtraction of the extremely highly expressed housekeeping genes or to excessive cycles of PCR amplification. Sampling mRNA at correct developmental stages of larval molting and metamorphosis, increasing the amount of driver cDNA used, reducing the number of PCR cycles, and sequencing more cDNAs might improve the efficacy of SSH in future studies.

Of the 11 genes upregulated during larval molting or metamorphosis, 8 were differentially detected during larval molting (HCS), including carbA1, irpp-inhibitor, hmg176, carbA2 and a tumor necrosis factor receptor (TNFR)-like gene, and 3 were differentially detected from metamorphically committed larvae, including the gamma subunit of guanine nucleotide binding protein (G-protein- $\gamma$ ), nuclear transport factor-2 (NTF-2) and rpL11. According to studies in Manduca, 20E levels peak during larval molting several hours before HCS and then decrease to lower levels while $\mathrm{JH}$ levels peak at larval ecdysis. 20E and JH again peak together at pupal commitment stage (wandering stages). After pupation, 20E peak again during pupal development [4]. Helicoverpa armigera belongs to Lepidoptera: Noctuidae and has similar 20E titer to M. sexta, which reaches peak levels during 5th and 6th larval molts and decreases to lower level during ecdysis [36]. The 11 differentially expressed genes detected in this study are likely regulated by the puff of $20 \mathrm{E}$, which present us new gene candidates for further study the functions and regulatory expression of these genes during larval molting or metamorphosis.

\section{Conclusion}

From the 100 ESTs identified from SSH of various tissues of $H$. armigera, we identified 11 that are differentially upregulated during larval molting or metamorphosis. In addition, we present several other candidates for further studies of larval molting or metamorphosis. These studies will extend our knowledge the regulatory mechanisms of holometabolous insect larval molting and the metamorphosis cascade.

\section{Methods}

\section{Insects}

The cotton bollworms, Helicoverpa armigera (Lepidoptera: Noctuidae), were reared on food composed mainly of wheat, soybean, vitamins, and inorganic salts, and maintained in a light:dark cycle of $14: 10 \mathrm{~h}$ at $27^{\circ} \mathrm{C}$. Developmental stages were defined as follows. Fifth- 0 h larvae: immediately after ecdysis with white head capsule (5th-0 h, WH). 5th instar larvae normally eat for $36 \sim 40 \mathrm{~h}$ and then head capsule slippage (HCS) occurs. HCS lasts for about $12 \mathrm{~h}$, during which larvae considered 5 th instarmolting larvae (5th-molting, or 5th-HCS). Next, larvae shed their cuticle in a few minutes and enter the 6th instar (6th-0 h, WH). Sixth instar larvae eat for $48 \mathrm{~h}$, then purge the gut and turn red, and begin wandering at $72 \mathrm{~h}$ (6th-72 h, W-0 d). Larvae continue wandering until 96 h (6th-96 $\mathrm{h}, \mathrm{W}-1 \mathrm{~d})$, then contract their legs and stop wandering at $120 \mathrm{~h}$ (6th-120 h, PP), and pupation begins at $140 \mathrm{~h}$ (P-0 h/d). Pupae are designated P-1 d, P-2 d, and so on. Pupae develop for $9 \sim 10 \mathrm{~d}$, depending on sex, until eclosion. According to studies in Manduca, 20E levels peak several hours before HCS and then begin to decrease. JH levels peak at larval ecdysis. 20E and JH again peak together at wandering and prepupal stages [4]. We prepared all samples for this study according to these developmental markers in individuals of equal body size.

\section{Isolation of mRNAs from issues and synthesis of CDNA}

Messenger RNA was isolated from epidermis, midguts, fat bodies, hemocytes, and heads at four developmental stages using Micro mRNA Isolation kit (Amersham, Uppsala, Sweden) following the manufacturer's protocol. Developmental stages included the 5th to 6 th instar transition, the feeding 6th instar stage (6th-48h), metamorphically committed larvae (6th-72, 96, and $120 \mathrm{~h}$ ), and feeding 5th instar larvae (5th-24 h). First strand cDNAs were synthesized using SMART subtract cDNA construction kit from Clontech (BD Bioscience Clontech, Mountain View, USA) from $2 \mu \mathrm{g}$ of mRNA with the following primers: 5' SMART CDS Primer II A Oligonucleotide and 3' SMART CDS Primer II A (5'-AAGCAGTGGTATCAACGCAGAGTACGCGGG-3', 5'-AAGCAGTGGTATCAACGCA$\operatorname{GAGTACT}_{(30)} \mathrm{N}_{-1} \mathrm{~N}_{-3}-33^{\prime}, \mathrm{N}_{-1}$ = ACG; $\mathrm{N}=$ ATCG). Second strands were synthesized from first strand CDNAs using PCR Primer II (5'-AAGCAGTGGTATCAACGCAGAGT-3').

\section{Suppression Subtractive Hybridization (SSH)}

Three kinds of SSH were performed, including tester cDNAs from five tissues from molting 5th instar larvae and driver cDNAs from five tissues from feeding 6 th instar larvae, tester cDNAs from five tissues from metamorphically committed larvae and driver cDNAs from five tissues from feeding 5 th instar, and tester cDNAs from five tissues of feeding 5 th instar larvae and driver cDNAs from five tissues from metamorphically committed larvae.

cDNAs from testers and drivers were first cut into fragments by RsaI digestion. Each cDNA from the testers was then separated into two portions and adapters 1 and $2 \mathrm{R}$ were each added to one of the two parts.

\section{5'-CTAATACGACTCACTATAGGGCTCGAGCG- GCCGCCCGGGCAGGT-3' adapter 1}




\section{3'-GGCCCGTCCA-5'}

5'-CTAATACGACTCACTATAGGGCAGCGTGGTCGCGGCCGAGGT-3' adaptor 2R

\section{3'-GCCGGCTCCA-5'}

Testers were then separately hybridized with excess drivers in a ratio of tester:driver 1:30 for the first hybridization, and followed a second hybridization by adding $1 \mu \mathrm{l}$ driver mixture $(1 \mu \mathrm{l}$ hybridization buffer, $1 \mu \mathrm{l}$ driver and $2 \mu \mathrm{l}$ water) to the first hybridization solution according to the Clontech PCR-Select cDNA SUBTRACTION kit protocol (BD Biosciences (BD Bioscience Clontech, Mountain View, USA). PCR amplification was then performed twice with PCR primer 1 (5'-CTAATACGACTCACTATAGGGC$3^{\prime}$ ) and nested PCR primers 1/primer 2R (5'-TCGAGCGGCCGCCCGGGCAGGT-3'/5'-AGCGTGGTCGCG-

GCCGAGGT-3'), to amplify differentially expressed genes.

\section{Cloning and identification of DNA fragments from SSH}

PCR products were purified and cloned into the pGEM TEasy vector (Promega Company (Biosciences, Madison, WI, United States) and transformed into Escherichia coli DH5 $\alpha$. Insert sizes were screened by PCR and were sequenced. A similarity search using each DNA fragment as a query was performed using the Basic Local Alignment Search Tool (BLASTX) [37] to identify the genes.

Preparation of digoxigenin-labeled anti-sense RNA probes Target genes were inserted into the pGEM-T Easy plasmid. Recombinant plasmids were linearized, depending on the insertion direction of the target gene, and were used as templates for in vitro transcription of anti-sense diglabelled probe using an RNA Labeling kit was used to synthesize the probe and the procedures were performed according to the manufacturer's suggestions (Boehringer Mannheim, Mannheim, Germany). The length of the target genes was about $500 \mathrm{bp}$.

\section{Preparation of digoxigenin-labeled DNA probes}

Complementary DNAs (cDNA) synthesized from mRNAs isolated from 5th and 6th instar epidermis were used as templates for synthesizing dig-labeled DNA probes. The probes were synthesized by random primed PCR using the Dig High Prime DNA Labeling and Detection Starter Kit (Boehringer Mannheim, Mannheim, Germany).

\section{Dot blot hybridization}

PCR products over 300 bp obtained by SSH were cloned into pGEM T-Easy plasmid and transformed into DH5 $\alpha$. Plasmids were amplified by PCR and the PCR products were quantified by agarose gel electrophoresis to choose candidates for dot blot hybridization. After denaturing for
10 min at $100^{\circ} \mathrm{C}$, chilling on ice, and $2 \mu \mathrm{l}$ of each PCR product was then dotted onto a positively-charged nylon membrane. After cross linking for 10 min under ultraviolet light, blots were prehybridized, hybridized, washed, and developed color. Prehybridization and hybridization were performed at $40^{\circ} \mathrm{C}$. The probe was denatured at $100^{\circ} \mathrm{C}$ for $5 \mathrm{~min}$ before use. The wash conditions were: 2 $\times$ SSC $+0.1 \%$ SDS for $2 \times 5$ min at room temperature, followed by $0.1 \times$ SSC $+0.1 \%$ SDS for $2 \times 15 \mathrm{~min}$ at $68^{\circ} \mathrm{C}$. Color development was achieved using the NBT/BCIP (nitroblue tetrazolium chloride/5-bromo-4-chloro-3indolyl phosphate) solution ( $45 \mu \mathrm{l} \mathrm{NBT} 50 \mathrm{mg} / \mathrm{ml}$ in $70 \%$ $\mathrm{v} / \mathrm{v}$ dimethylformamide, plus $35 \mu \mathrm{l}$ BCIP $50 \mathrm{mg} / \mathrm{ml}$ in $100 \%$ dimethylformamide).

\section{Northern blot}

Approximately $10 \mu \mathrm{g}$ of total RNA was denatured and electrophoresed in a 5\% formaldehyde-containing agarose gel. After electrophoresis, the RNA was transferred onto a nylon membrane. Target mRNA was prehybridized for $2 \mathrm{~h}$ and hybridized with dig-labeled antisense RNA probe $(100 \mathrm{ng} / \mathrm{ml}$ final concentration) in Northern hybridization buffer, at $68^{\circ} \mathrm{C}$ overnight. After the stringency wash at $68^{\circ} \mathrm{C} 2 \times \mathrm{SSC}+0.1 \% \mathrm{SDS}$ for $2 \times 5 \mathrm{~min}$ at room temperature, followed by $0.1 \times$ SSC $+0.1 \%$ SDS for $2 \times 15 \mathrm{~min}$ at $68^{\circ} \mathrm{C}$, anti-dig-Phosphatase AP antibody (1:10000 diluted in buffer 2, $100 \mathrm{mM}$ maleic acid, 150 $\mathrm{mM} \mathrm{NaCl} ; \mathrm{pH} 7.5,1 \%$ blocking reagent) was used to detect the probe at $37^{\circ} \mathrm{C}$. NBT and BCIP were used to visualize the signals as description above. All steps were carried out as recommended by the manufacturer (Roche).

\section{Semi-quantitative reverse transcription-PCR (Semi- quantitative RT-PCR)}

Total RNA was isolated from epidermis, midguts, fat bodies, hemocytes and heads of molting 5th instar and feeding 6th instar larvae. Complementary DNAs (cDNA) were then synthesized. The beta-actin gene was used as a cDNA quantity control. PCR conditions were as follows: $94^{\circ} \mathrm{C}$ for $2.5 \mathrm{~min}$, and then $23 \mathrm{cycles}$ of $94^{\circ} \mathrm{C}$ for $45 \mathrm{~s}, 53^{\circ} \mathrm{C}$ for $1 \mathrm{~min}$ and $72^{\circ} \mathrm{C}$ for $1 \mathrm{~min}$, followed by a single cycle at $72^{\circ} \mathrm{C}$ for $10 \mathrm{~min}$. The primers used are listed in Table 4 .

\section{Authors' contributions}

Du-Juan Dong constructed the SSH library and analyzed the DNA sequences. Hong-Juan He constructed the SSH library and analyzed the DNA sequences. Lian-Qin Chai carried out RT-PCR and Northern blot. Xiao-Juan Jiang constructed the SSH library and did Dot blot hybridization and Northern bolt. Jin-Xing Wang participated in its design and coordination. Xiao-Fan Zhao participated in the design of the study and drafted the manuscript. All authors read and approved the final manuscript. 
Table 4: List of primers for semi-quantitative RT-PCR

\begin{tabular}{|c|c|c|}
\hline Number & genes & primers \\
\hline 1 & carboxypeptidase Al & CarbAIF2 5'-gcattatcttgattcgggtc-3' CarbAIRT 5'-catcttgcccacagtttc-3' \\
\hline 2 & cathepsin L & CathLFI 5'-gcggaatacggacaatacac-3' CathLR2 5'-tagtgattagcgtggtcgcg-3' \\
\hline 3 & lipopolysaccharide binding protein & LipoF2 5'-acttcgctgcagtcttcaag-3' LipoR2 5'-cgtcgtgcctgtgctattgc-3' \\
\hline 4 & immune reactive putative protease inhibitor & InhibiFI 5'-tttgagttgcgttgtggtgg-3' InhibiR2 5'-tcaccaacaggtatgcattc-3' \\
\hline 5 & lipase & LipaseF2 5'-aggatttggggcgatttcatc-3' LipaseR2 5'-ttggtcaagcagcctggttg-3' \\
\hline 6 & trypsinogen $Y$ precursor & TrypF2 5'-ggttggggaagtcgaaactc-3' TrypR2 5'-ctcaggaaaagctctaacag-3' \\
\hline 7 & conserved hypothetical protein [Lactococcus lactis] & LactF2 5'-ttagttaccaagattggctc-3' LactR2 5'-gaatgtcaaaccacttgtgc-3' \\
\hline 8 & titin-like protein & TitinFI 5'-gaggaaatcgttgacgacac-3' TitinR2 5'-tttctaccttcggacctacc-3' \\
\hline 9 & Na-K-ATPase & ATPaseF2 5'-atactgaggacctgccttcc-3' ATPaseR2 5'-actggcccgatgttctccac-3' \\
\hline 10 & hmgI76 & HMG I76F 5'-atgaaaagtttccttgtcatc-3' HMG I76R 5'-cttaatctaaccaagaaaccac-3' \\
\hline 11 & carboxypeptidase $\mathrm{A} 2$ & CarbA2F2 5'-ccagaatctaaagcaattgc-3' CarbA25-P 5'-aaagccttaacggccagtgtc-3' \\
\hline 12 & tissue plasminogen activator & tPAF2 5'-tggtatcaacgcagagtagc-3' tPAR3 5'-atgagagtatttgcccgtgg-3' \\
\hline 13 & thymosin beta homologue & ThymoFI 5'-ggaacccaaaccggttcaag-3' ThymoR I 5'-attcagtcttgtcagcgacc-3' \\
\hline 14 & TNF receptor homolog 3 & TNFFI 5'-aagtttccttgtcatcgccc-3' TNFRI 5'-ctactagaagctcctgtgtc-3' \\
\hline 15 & unknown EST & UNFI 5'-aacatgtcccagcggctaac-3' UNRI 5'-tcaacctgtcagcgtgacag-3' \\
\hline 16 & ribosome protein $\$ 23$ & S23F 5'-ggtacgcgggattgaagagaacg-3' S23R 5'-caacacagctttgcagcagcagg-3' \\
\hline 17 & ribosome protein L27 & L27F 5'-cctcagacaagccctacggac-3' L27R 5'-ctcttgtatctctcctcgaag-3' \\
\hline 18 & ribosome protein S7 & S7F 5'-catccggatcaagctcgacgg-3' S7R 5'-ttcctaagtttacaagtaggg-3' \\
\hline 19 & ribosome protein LII & LI IF 5'-catctgtgtgggagagtctggtg-3' LI IR 5' - gtgttgtcagtctcactcgctgc-3' \\
\hline 20 & G-protein- $\gamma$ & Gpro $\gamma$ 5'-atggatatgatggtatcaacg-3' Gpro $\gamma$ 5'-ttaaagaacagtgcaggaact-3' \\
\hline 21 & NTF-2 & NTF2F 5'-atggcgctcaatccacaatac-3' NTF2R 5'-ctttgaaggagtacagttgca-3' \\
\hline 22 & ecdysteroid-regulated gene & EcdyrF 5'-ctgcaggatgccgtcatac-3' EcdyrR 5'-ctaggcgcgcggaggagcgat-3' \\
\hline 23 & beta-actin & ActinF 5'-agtagccgccctggttgtagac-3' ActinR 5'-ttctccatgtcgtcccagt-3' \\
\hline
\end{tabular}

\section{Accession numbers}

Accession numbers of the putative genes and unknown expression sequence tags (ESTs) in this study are: [GenBank: DQ875214-DQ875283 and EE332468EE332497].

\section{Acknowledgements}

This work was supported by grants from the Natural Science Foundation of China (No: 30330070; 30670265), the Special Fund for the Major State Basic Research Project (2006CBI0200I), and the Natural Science Foundation of Shandong Province (No.Z2003D04).

\section{References}

I. Mesce KA, Fahrbach SE: Integration of endocrine signals that regulate insect ecdysis. Front Neuroendocrinol 2002, 23:179-199.

2. Lee CY, Wendel DP, Reid P, Lam G, Thummel CS, Baehrecke EH: E93 directs steroid-triggered programmed cell death in Drosophila. Mol Cell 2000, 6:433-43.

3. Thummel CS: Steroid-triggered death by autophagy. BioEssays 200I, 23:677-682.

4. Riddiford LM, Hiruma K, Zhou X, Nelson CA: Insights into the molecular basis of the hormonal control of molting and metamorphosis from Manduca sexta and Drosophila melanogaster. Insect Biochem Mol Biol 2003, 33:|327-1338.

5. Riddiford LM, Cherbas P, Truman JW: Ecdysone receptors and their biological actions. Vitam Horm 2000, 60: I-73.

6. Frand AR, Russel S, Ruvkun G: Functional Genomic Analysis of C. elegans Molting. PLoS Biol 2005:1719-1733.

7. Yin VP, Thummel CS: Mechanisms of steroid-triggered programmed cell death in Drosophila. Semin Cell Dev Biol 2005, 16:237-243

8. White KP, Rifkin SA, Hurban P, Hogness DS: Microarray analysis of Drosophila development during metamorphosis. Science 1999, 286:2179-2184.
9. Beckstead RB, Lam G, Thummel CS: The genomic response to 20-hydroxyecdysone at the onset of Drosophila metamorphosis. Genome Biol 2005, 6:R99.

10. Li TR, White KP: Tissue-specific gene expression and ecdysone-regulated genomic networks in Drosophila. Dev Cell 2003, 5:59-72.

II. Arbeitman MN, Furlong EE, Imam F, Johnson E, Null BH, Baker BS, Krasnow MA, Scott MP: Gene expression during the life cycle of Drosophila melanogaster. Science 2002, 297:2270-2275.

12. Zhao X-F, Wang J-X, Xu X-L, Li Z-M, Kang C-J: Molecular cloning and expression patterns of molt-regulating transcription factor-hhr3 from Helicoverpa armigera. Insect Mol Biol 2004, I3:407-4/2.

13. Zhao X-F, He H-J, Dong D-J, Wang J-X: Identification of Differentially Expressed Proteins during Larval Molting of Helicoverpa armigera. J Proteome Res 2006, 5:164-169.

14. Diatchenko L, Lau Y-FC, Campbell AP, Chenchik A, Moqadam F, Huang B, Lukyanov S, Lukyanov K, Gurskaya N, Sverdlov ED, Siebert PD: Suppression subtractive hybridization: A method for generating differentially regulated or tissue-specific CDNA probes and libraries. Proc Natl Acad Sci USA 1996, 93:6025-6030.

15. Gurskaya NG, Diatchenko L, Chenchik A, Siebert PD, Khaspekov GL, Lukyanov KA, Vagner LL, Ermolaeva OD, Lukyanov SA, Sverdlov ED: Equalizing cDNA subtraction based on selective suppression of polymerase chain reaction: Cloning of Jurkat cell transcripts induced by phytohemaglutinin and phorbol I2-myristate I3-acetate. Anal Biochem 1996, 240:90-97.

16. Ote M, Mita K, Kawasaki H, Daimon T, Kobayashi M, Shimada T: Identification of molting fluid carboxypeptidase A (MF-CPA) in Bombyx mori. Comp Biochem Physiol B Biochem Mol Biol 2005, 141:314-322.

17. Guiliano DB, Hong X, McKerrow JH, Blaxter ML, Oksov Y, Liu J, Ghe$\operatorname{din} \mathrm{E}$, Lustigman S: A gene family of cathepsin L-like proteases of filarial nematodes are associated with larval molting and cuticle and eggshell remodeling. Mol Biochem Parasitol 2004, 136:227-242.

18. Bhattacharya A, Steward R: The Drosophila homolog of NTF-2, the nuclear transport factor-2, is essential for immune response. $E M B O \operatorname{Rep} 2002,3: 378-383$. 
19. Hewes RS, Schaefer AM, Taghert PH: The cryptocephal gene (ATF4) encodes multiple basic-leucine zipper proteins controlling molting and metamorphosis in Drosophila. Genetics 2000, 155:17|I-1723.

20. Jones G, O'Mahony P, Chang S, Schachtschabel U: Identification of regulatory sequences of juvenile hormone-sensitive and insensitive serum protein-encoding genes. Gene 1996, 173:209-2|4.

21. Purdy A, Uyetake L, Cordeiro MG, Su TT: Regulation of mitosis in response to damaged or incompletely replicated DNA require different levels of Grapes (Drosophila Chkl). J Cell SCi 2005, II 8:3305-3315.

22. Costanzi J, Sidransky D, Navon A, Goldsweig H: Ribonucleases as a novel pro-apoptotic anticancer strategy: review of the preclinical and clinical data for ranpirnase. Cancer Invest 2005 , 23:643-650.

23. Kasai H, Nadano D, Hidaka E, Higuchi K, Kawakubo M, Sato TA, Nakayama J: Differential expression of ribosomal proteins in human normal and neoplastic colorectum. J Histochem Cytochem 2003, 5 I:567-574.

24. Gray JP, Davis JW, Gopinathan L, Leas TL, Nugent CA, Vanden Heuvel JP: The ribosomal protein rpLI I associates with and inhibits the transcriptional activity of peroxisome proliferatoractivated receptor-alpha. Toxicol Sci 2006, 89:535-546.

25. Dai MS, Zeng SX, Jin Y, Sun XX, David L, Lu H: Ribosomal protein L23 activates $p 53$ by inhibiting MDM2 function in response to ribosomal perturbation but not to translation inhibition. Mol Cell Biol 2004, 24:7654-7668.

26. Jin A, Itahana K, O'Keefe K, Zhang Y: Inhibition of HDM2 and activation of p53 by ribosomal protein L23. Mol Cell Biol 2004, 24:7669-7680.

27. Yoo YA, Kim MJ, Park JK, Chung YM, Lee JH, Chi SG, Kim JS, Yoo YD: Mitochondrial ribosomal protein L4I suppresses cell growth in association with p53 and p27Kipl. Mol Cell Biol 2005, 25:6603-6616

28. Kim MJ, Yoo YA, Kim HJ, Kang S, Kim YG, Kim JS, Yoo YD: Mitochondrial ribosomal protein L4I mediates serum starvationinduced cell-cycle arrest through an increase of p2I(WAFII CIP I). Biochem Biophys Res Commun 2005, 338: I I79-II84.

29. Khanna N, Sen S, Sharma H, Singh N: S29 ribosomal protein induces apoptosis in $\mathbf{H 5 2 0}$ cells and sensitizes them to chemotherapy. Biochem Biophys Res Commun 2003, 304(I):26-35.

30. Khanna N, Reddy VG, Tuteja N, Singh N: Differential gene expression in apoptosis: identification of ribosomal protein $\mathbf{S 2 9}$ as an apoptotic inducer. Biochem Biophys Res Commun 2000 277:476-486.

31. Squires $C L$, Zaporojets D: Proteins shared by the transcription and translation machines. Annu Rev Microbiol 2000, 54:775-798.

32. Russell VW, Dunn PE: Lysozyme in the midgut of Manduca sexta during metamorphosis. Arch Insect Biochem Physiol I991, I 7:67-80.

33. Inohara N, Nunez G: $M L$ - a conserved domain involved in innate immunity and lipid metabolism. Trends Biochem Sci 2002, 27:219-2I

34. Mahoney JA, Ntolosi B, DaSilva RP, Gordon S, McKnight AJ: Cloning and characterization of CPVL, a novel serine carboxypeptidase, from human macrophages. Genomics 200I, 72:243-25I.

35. Harris J, Schwinn N, Mahoney JA, Lin HH, Shaw M, Howard CJ, da Silva RP, Gordon S: A vitellogenic-like carboxypeptidase expressed by human macrophages is localized in endoplasmic reticulum and membrane ruffles. Int J Exp Pathol 2006 , 87:29-39.

36. Liu J, Shi G-P, Zhang W-Q, Zhang G-R, Xu W-H: Cathepsin L function in insect moulting: molecular cloning and functional analysis in cotton bollworm, Helicoverpa armigera. Insect Mo Biol 2006, I 5(6):823-834.

37. BLASTX [http://www.ncbi.nlm.nih.gov.]

\section{Publish with Bio Med Central and every} scientist can read your work free of charge

"BioMed Central will be the most significant development for disseminating the results of biomedical research in our lifetime. "

Sir Paul Nurse, Cancer Research UK

Your research papers will be:

- available free of charge to the entire biomedical community

- peer reviewed and published immediately upon acceptance

- cited in PubMed and archived on PubMed Central

- yours - you keep the copyright

Submit your manuscript here:

http://www.biomedcentral.com/info/publishing_adv.asp
BioMedcentral 